\title{
Making PROFIT at the Intermodal Terminal - A Research Agenda
}

\author{
Torbjörn H. Netland and Ingrid Spjelkavik \\ Department of Industrial Management, SINTEF Technology and society, \\ S.P. Andersens veg 5, 7465 Trondheim, Norway \\ torbjorn.netlandasintef.no
}

\begin{abstract}
Intermodality has been a hot topic in the logistics sector for several decades, but the expected diffusion into business is still limited. The key to increased intermodalism lies at the intermodal terminal. This paper puts forward four literature-based propositions that should be part of the future research agenda for intermodal terminals. In order to realise the intermodal terminal of the future, there is a need to: (P1) develop an effective operative terminal system, (P2) develop a holistic performance measurement system for the terminal, (P3) develop cooperation models for the network actors, and (P4) develop new value increasing services at the terminal.
\end{abstract}

Keywords: Intermodality, terminal, logistics.

\section{Introduction}

Due to today's global competition in logistics services and the focus on environmentfriendly transport, intermodal transportation is increasingly achieving attention. For intermodal transportation networks to be effective it is required that the main goods flows are routed through centralised nodes where the goods are efficiently transhipped to other carrying units. The transhipment can be between similar modes (rail-rail, road-road etc.) or different modes of transport (rail-road, sea-road etc.). Thus, the terminal is the key to achieve competitiveness in intermodal networks. It is at the terminal that the "inter"-aspect of intermodality is realised.

The purpose of this paper is to put forward a set of literature-based propositions that should be part of the future research agenda for intermodal terminals. The paper is written as a conceptual point of departure for the Norwegian research project PROFIT (Project Future Intermodal Terminals) 2009-2011, with a vision to "develop the terminal from a cost centre to a central node for value creation in the future intermodal logistic networks" [1].

The paper presents a literature review on intermodal transport with a focus on terminals and discusses relevant future research areas. Databases such as Bibsys, Ei Compendex, ABI, ISI and other databases were searched for books and papers with the keywords "terminals", "intermodality", "port" and "intermodal transport", combined with "freight transport", "container", "performance management" and "operations management" in title and abstract. Reference lists in the found articles and 
books where searched for additional relevant literature. The theory discussions end into a set of literature-based propositions for the future research agenda on intermodal terminals.

\section{Research on Intermodality at Terminals}

Research on intermodality at terminals is not new. The invitation programme for the Second Conference on Intermodal Freight Terminal Design, held in New Orleans in March 1986, clearly emphasises a topic that is as relevant today as it was twenty years ago:

"There are more and more and larger and larger conferences on the intermodal subject every year. The aim of this conference, however, was to focus appropriate attention to the most costly element of intermodal services: the terminal. The conference theme 'Facing the Challenge-The Intermodal Terminal of the Future', was borne out by a program that featured the latest examples of the technologies involved" [2].

\subsection{Defining Intermodality}

A wide variety of definitions of intermodality exists. In this paper we adopt the definition of intermodal transport put forward by OECD [3]: "Intermodal transport indicates the use of at least two different modes of transport in an integrated manner in a doorto-door transportation chain". This definition underpins the distinction between intermodalism and multimodalism: According to Chatterjee and Lakshmanan [4] multimodalism simply means transport by multiple modes, and has existed for hundreds of years since early cargo sea shipment and the first years of the railway. Intermodalism, on the other hand, has grown since the 1980s, and involves standardised and integrated interfaces between modes. In other words; intermodal transport is similar to multimodal transport but puts more emphasis on connectivity of different transport modes [5]. It is exactly this connectivity or interconnectivity that gives a seamless transportation chain that is the key to future success of intermodal transport. Intermodalism as it exists today is far from seamless, and the most important issue is how to build the seams by reducing transaction costs at the transfer points [4]. Thus, the seamless interconnectivity can only be ensured at the terminal.

\subsection{Drivers for Increased Intermodal Transport}

There are several reasons for the growth of intermodal transportation systems. Chatterjee and Lakshmanan [4] outline four main macro drivers towards increased intermodal transport:

One macro trend is globalisation. Globalisation encourages increased intermodal transportation through the growth of international and interregional trade agreements and unions (e.g. GATT, WTO, NAFTA, and EU) that leads to free competition in earlier regulated national markets. In addition global production and global sourcing substantially increase the need for transport in general. 
Technological innovation, containerisation in particular, is another macro driver. The container, measured in TEU (Twenty-foot equivalent units), allows for standardisation and gives predictability and robustness in global transportation networks and is the clearly most referred reason for intermodal growth. Other key technological drivers for increased intermodality are advanced container ships and RO-RO-ships, double-stack trains, piggyback rail solutions, general ICT-developments such as web portals, EDI and advanced business software, ITS technologies (Intelligent Transportation System), auto-id technologies giving visibility such as AVL, GPS, DGPS (Differential GPS), and handling technologies and machines such as for example gantry cranes with capacity of 40 container moves per hour.

Some recent political and commercial reforms in the transportation sector also encourage the growth of intermodal transport. Deregulation of national transportation markets (in particular road and rail) is a typical example of a institutional reform that leads to free competition and the development of competitive intermodal transportation. Other organisational reforms have led to new business models, consisting among others of specialised freight forwarders, container leasing companies, consolidators that take LTL (less-than-truckload), custom brokers, intermodal terminal operators, and third party and fourth party logistics providers. Many of these new business models are ready to reap the advantage of better intermodal infrastructure.

Finally, the global trend in manufacturing industry to become more lean and efficient is changing transportation from push to pull logistics systems. The Just-in-time principle introduced by Toyota in the 1960s was picked up by the Western manufacturing industry in the $1980 \mathrm{~s}$, and is more popular today than ever. Just-in-time production requires smaller volumes and more frequent supply with a track-and-trace and cost efficiency focus.

\subsection{Two Main Streams of Research}

In particular two streams of research fields are dominating the literature on intermodal terminals today:

(1) Operations Research (OR) on both a macro view (e.g. network optimisation) and a micro view (e.g. crane move optimisation) [e.g. 6, 7, 8, 9]

(2) Transportation infrastructure and communication (often state-funded research with political implications) [e.g. 10, 11, 12, 13]

Intermodal transportation networks have received much attention from Operation Research (OR) disciplines using mathematical programming techniques to optimise the design of location and flow in networks. A reason for this might be that "logistics and transportation have been among the most successful application areas of OR" [6]. OR-research on terminal logistics is concerned with issues such as network optimisation, location analysis, planning algorithms for container stacking, fleet management optimisation, crane utilisation optimisation, berth management optimisation, allocation of storage space, and so on. OR-research indisputable has a powerful contribution in regard to increasing the effectiveness and efficiency of logistics networks and terminal operations, but OR-research alone will not lead to great increase in intermodal transportation. 
Intermodal transportation networks has also been heavily analysed from a public perspective on transportation infrastructure and communication. In his rather extensive book on Intermodal Freight Transport, David Lowe [10] recognises the importance of the terminal; "A network of strategically located and fully equipped transfer terminals $(. .$.$) is critical to the development of international combined transport op-$ erations. But yet, throughout his book Lowe put very limited emphasis on the subject; only five out of 276 pages directly discuss the freight interchange at terminals (pages 142-146). Much is written about intermodality from this political macro perspective, but great practical examples of intermodal transport are still relatively rare in these studies.

Common for both research streams is an underlying focus on performance, because improving performance (throughput, cost effectiveness, speed, quality, reliability etc) is the overall remedy of creating competitive intermodal terminals. Altogether there seems to be three reasons for performance measurement in transports according to Meyer [14] and Humphreys and Graham [15]: (1) Measurements of the effects of public investments in transports, (2) measurements as a basis for decision making and strategies for investments in transport, and (3) measurements for following up and identification of improvements within the transporting companies. Fagerhaug and Olsson [13] studied state-of-the-art in performance measurement within railroad, transport and found that the reason for performance measurement in transports is to achieve continuously improvements in operations and results, but what actually is being measured, is productivity in the sense of output in relation to input. Gosling [16] also calls on measuring outcomes rather than outputs, to measure customer satisfaction, measures relevant for strategy processes and decision making

\section{Discussion on Challenges to Be Met}

\subsection{Operational Challenges}

Despite the political drivers towards increased intermodal transportation, intermodalism is still in its early stages of development [4], and the market share of intermodal transport is still low, and moreover, is not showing a significant increase [17, 18]. There are several reasons for this slow diffusion of intermodality into praxis; First and foremost, the unbiased cost focus in the Europeans transport sector [18] has led to hard entry conditions for new transportation systems such as intermodality. Especially the time- and cost handicap of intermodal transportation due to the transhipment, and it's still inferior frequency, is hindering intermodal growth [11]. Also technological and infrastructural factors are still obstacles [17], as an example there are 37 different combinations of rail gauge, tunnel clearance and power systems in Europe [18]. Another technological challenge is the lack of standardisation of swap bodies [11]. But first and foremost, intermodal competitiveness is tied to operational effectiveness and efficiency at the terminal.

In order to reap the full environmental and corporate benefits of intermodal transportation systems, the successful intermodality at sea must be passed forward to inland transportation modes. While the diffusion of intermodality in the inland transportation systems has been slow, global intermodality has been very successful on sea [19]. The 
European inland intermodal success is mainly tied to the Alpine crossing and the transport between the main seaports and their hinterland [11]. Inland intermodal transportation systems are rare in practice. Intermodal shipping has 30 years of success. It is the shipping industry that developed the standardised container, not rail- and road actors. According to Stone [19], successful marine intermodal terminals have passed through four development phases: (1) Making it work, (2) Handling the growth of demand, (3) Reducing the system cost, and (4) Managing the performance. The four suggested phases are maturity levels with thresholds that must be overcome in order to reach the next maturity phase. Now is the time to realise the fact that "containerisation and intermodality have strengthened the symbiotic relationship between foreland and hinterland in the sense that a true foreland-hinterland continuum has come to existence [20]". Making it work implies a first focus on operational effectiveness.

Based on this discussion we propose that a first challenge to solve should be to (P1) develop an effective operative terminal system.

\subsection{Performance Challenges}

Several authors [19, 21, 22] ask for better performance measurement systems at terminals. The terminal must meet the requirements of the transportation network. Terminals should change from production-oriented (internal processes) to customeroriented [21]. Metz [23] and Bustinduy [24] focuses on quality as the key to success. But container terminals have no tradition for quality measurement [21].

In the future development of performance perspective within intermodal terminals we should look for advice in the statements of Konings et al [17] and their three determinants for the performance of intermodal transport and its potential role as an alternative mode for road transport (1) intermodal transport operations, (2) design and modelling and (3) implementation and policy. The development of a performance measurement system for the terminal should provide transparency in the logistic network, and support and emphasise the behaviour that ensures efficiency in the flow of containers. The performance measurement system should be a tool for different users of the future intermodal terminal. There is also a lack of performance indicators for intermodal terminals that should be answered in future research.

Based on this we propose that a second challenge to solve is to $(P 2)$ develop a holistic performance measurement system for the terminal.

\subsection{Network Challenges}

One major obstacle to increased intermodalism is that the investments has to be taken by one or two actors (rail infrastructure owners and terminal operators), while the gains are partially reaped by the logistic service companies, and certainly also passed forward to the most powerful actor in the supply chain - the goods owners (retail chains, manufacturing companies etc). The latter group is decoupled from all investments in rail and terminal infrastructure. In short; most cost for quality improvement occurs at the terminal, while most benefits are reaped in the network [21]. Halseth [12] found that it has been extremely difficult to study cooperation models at Norwegain intermodal terminals, because independent transportation providers has sought competition rather than cooperation, and has not been willing to share data and information with researchers and competitors. 
Another major obstacle to increase intermodalism is the total absence of crossactor IT-infrastructure in the transportation industry. Typically transportation service providers mainly have their in-house-developed IT-system, and this system is regarded as one of the competitive advantages of the firm. This is not unlike the situation in manufacturing industries some two decades ago. In today's manufacturing industries all actors use one out of a limited number of available ERP-systems (Enterprise Resource Planning) (e.g. SAP, Microsoft Dynamics, Microsoft Navision, ERP-LN etc.), that are able to communicate almost seamless with each other through EDI-standards (Electronic Data Interchange). Even though the transportation industry increasingly implements EDI-solutions and especially sea ports' IT-systems (yard management systems) are well developed, much can be learned and transferred from manufacturing industries focus on supply chain management to achieve increased intermodal transportation. Halseth [12] stresses that the use of EDI for consignment notes between major Norwegian logistics providers and their customers has grown as a result of a joint industry initiative in the 90s. Thus major innovations in the transportation industry will not succeed if left to single actors.

Based on this we propose that a third challenge to solve should be to (P3) develop cooperation models for the network actors.

\subsection{Innovation Challenges}

The transportation industry has traditionally a very low degree of research and development. New innovative technologies do only have a limited and slow diffusion into terminals [25]. Incremental innovations in transportation networks are probably the best way to proceed [12]. If new services shall become attractive there is need for compatibility with existing solutions. Conservative logistics providers seek quick return on investment. Nevertheless, there is a need for dramatic innovations in order to tempt more goods to intermodal transportation systems.

Risjenbrij [26] discusses how hinterland terminals can expand their services in order to remove operations and improve throughput in even more pressured mainport terminals. Operations that can be "outsourced" include stripping, customs handling etc. This is in line with the Agile Port System [27] that aims to split the port terminal into an Efficient Marine Terminal (EMT) ashore and an Intermodal Interface Centre (IIC) inland. Wiegmans et al. [21] stress that "to make the container terminal - and the transport service it forms part of - more competitive, it is necessary to offer a total service package (...). Terminals should offer a one-stop-shopping total service, that includes pre- and end- haulage, and not only container handling.

Therefore we propose that a fourth challenge to solve is to (P4) develop new value increasing services at the terminal.

\section{Conclusions and Future Research}

Based on the literature reviewed the authors put forward four propositions. In order to realise the future intermodal terminals there is a need to:

(P1) Develop an effective operative terminal system

(P2) Develop a holistic performance measurement system for the terminal 
(P3) Develop cooperation models for the network actors

(P4) Develop new value increasing services at the terminal

These four propositions will be addressed in the remainder of the research project PROFIT. While the literature review indicates that the macro perspective is a commonly used approach in transport literature, the approach of the PROFIT project is the micro perspective as working with the cluster of companies involved in the interaction at the terminal. This conceptual paper will be followed by empirical case studies in the business cluster around Oslo port and the Alnabru freight terminal.

\section{References}

1. PROFIT web page, http://www.sintef.no/profit

2. US Transportation Research Board: Facing the challenge: The intermodal freight terminal of the future. In: Conference on Intermodal Freight Terminal Design, New Orleans. Stateof-the-art report no. 4, Transportation Research Board, National Research Council, USA, p. iii (1986)

3. OECD: Benchmarking intermodal freight transport, Paris (2002)

4. Chatterjee, L., Lakshmanan, T.R.: Inermodal freight transport in the United States. In: Konings, R., Priemus, H., Nijkamp, P. (eds.) The Future of Intermodal Freight Transport. MPG Nooks Ltd., Bodmin (2008)

5. Taniguchi, E., Nemoto, T.: Intermodal freight transport in urban areas in Japan. In: Konings, R., Priemus, H., Nijkamp, P. (eds.) The Future of Intermodal Freight Transport. MPG Nooks Ltd., Bodmin (2008)

6. Andersen, J.: New service network design models for intermodal freight transportation, philosophia doctor thesis, Norwegian University of Science and Technology, Thesis number 2008:41, Trondheim, Norway (2008)

7. Kim, K.W., Günther, H.-O. (eds.): Container terminals and cargo systems - design, operations management and logistics control issues. Springer, Heidelberg (2007)

8. Steenken, D., Voß, S., Stahlbock, R.: Container terminal operation and operations research - a classification and literature review. OR Spectrum 26, 3-49 (2004)

9. Macharis, C., Bontekoning, Y.M.: Opportunities for OR in intermodal freight transport research: A review. European Journal of Operational Research 153, 400-416 (2004)

10. Lowe, D.: Intermodal Freight Transport. Elsevier/Butterworth-Heinemann, Oxford/UK (2005)

11. Woxenius, J., Bärthel, F.: Intermodal road-rail transport in the European Union. In: Konings, R., Priemus, H., Nijkamp, P. (eds.) The Future of Intermodal Freight Transport. MPG Nooks Ltd., Bodmin (2008)

12. Halseth, A.: Strategier og rammebetingelser for intermodal transport - Oppsummeringsrapport, ECON Pöyry Forskningsrapport 2004-014 (2004)

13. Fagerhaug, T., Olsson, N.: PEMRO Arbeidspakke 1.2. State of the art innenfor prestasjonsmåling, Report SINTEF Technology and society (2005)

14. Meyer, M.D.: Measuring System Performance: Key to Establishing Operations as a Core Agency Mission. Transportation Planning and Analysis. Transportation research record (1817), 155-162 (2002)

15. Humphreys, I., Francis, G.: Traditional Airport Performance Indicators: A Critical Perspective. Issues, problems, and performance measures in airports and airspace Transportation research record (1703), 24-30 (2000) 
16. Gosling: Aviation system performance measures for state transportation planning. Issues, problems and performance measures in airports and airspace. Transportation research record (1703), 7-15 (2000)

17. Konings, R., Priemus, H., Nijkamp, P.: The Future of Intermodal Freight Transport; an overview. In: Konings, R., Priemus, H., Nijkamp, P. (eds.) The Future of Intermodal Freight Transport. MPG Nooks Ltd., Bodmin (2008)

18. Tsamboulas, D.: Development strategies for intermodal transport in Europe. In: Konings, R., Priemus, H., Nijkamp, P. (eds.) The Future of Intermodal Freight Transport. MPG Nooks Ltd., Bodmin (2008)

19. Stone, B.: Critical success factors: interconnectivity and interoperability. In: Konings, R., Priemus, H., Nijkamp, P. (eds.) The Future of Intermodal Freight Transport. MPG Nooks Ltd., Bodmin (2008)

20. Notteboom, T.: Bundling freight flows and hinterland network development. In: Konings, R., Priemus, H., Nijkamp, P. (eds.) The Future of Intermodal Freight Transport, p. 66. MPG Nooks Ltd., Bodmin (2008)

21. Wiegmans, B., Nijkamp, P., Rietvald, P.: Conatiner ternminal hanling quality. In: Konings, R., Priemus, H., Nijkamp, P. (eds.) The Future of Intermodal Freight Transport. MPG Nooks Ltd., Bodmin (2008)

22. Janic, M.: An assessment of the performance of the European long intermodal freight trains (LIFTS). Transportation Research Part A: Policy and Practice 42(10), 1326-1339 (2008)

23. Metz, D.: Journey quality as the focus of future transport policy, Transport Policy (2005) (article in Press)

24. Bustinduy, J.: More quality in regional transport. In: Public Transport 1995, 51st International Congress. Paris 1995, International Commision on Regional Transport (1995)

25. Kreutzberger, E.: The impacts of innovative technical concepts for load unit exchange on the design of intermodal freight bundling networks. In: Konings, R., Priemus, H., Nijkamp, P. (eds.) The Future of Intermodal Freight Transport. MPG Nooks Ltd., Bodmin (2008)

26. Risjenbrij, J.: Container handling in mainports: a dilemma about future scales. In: Konings, R., Priemus, H., Nijkamp, P. (eds.) The Future of Intermodal Freight Transport. MPG Nooks Ltd., Bodmin (2008)

27. Franke, K.-P.: A technical approach to the Agile Port System. In: Konings, R., Priemus, H., Nijkamp, P. (eds.) The Future of Intermodal Freight Transport. MPG Nooks Ltd., Bodmin (2008) 